\title{
Highly Efficient Elastomeric Fluorescence Sensors for Force Detection
}

Daniel Heras ${ }^{\dagger}$, Marta Reig ${ }^{\dagger}$, Núria Llorca-Isern ${ }^{\ddagger}$, Jaume Garcia-Amorós ${ }^{\dagger}$ and Dolores Velasco ${ }^{\dagger, *}$

${ }^{\dagger}$ Grup de Materials Orgànics, Institut de Nanociència i Nanotecnologia (IN²UB), Departament de Química Inorgànica i Orgànica (Secció de Química Orgànica), Universitat de Barcelona, Martí i Franquès 1, E-08028, Barcelona, Spain

†Departament de Ciència dels Materials i Química Física (Secció de Ciència dels Materials), Universitat de Barcelona, Martí i Franquès 1, E-08028, Barcelona, Spain

*dvelasco@ub.edu 
Synthesis. Chemicals were purchased from commercial sources and used as received with the exception of THF, which was distilled over sodium and benzophenone. Commercially available anhydrous DMF was stored over activated $4 \AA$ molecular sieves under a nitrogen atmosphere. Thiophene-free toluene was prepared by washing commercially available toluene with concentrated sulfuric acid until the acid layer was colorless. The organic layer was washed twice with water, once with a potassium carbonate solution $(10 \% \mathrm{w} / \mathrm{w})$, again with water, dried over anhydrous $\mathrm{CaCl}_{2}$ and finally distilled through an efficient column. Thiophene-free toluene was stored over activated $5 \AA$ molecular sieves. ESIMS were recorded with a LC/MSD-TOF Agilent Technologies spectrometer. NMR spectra were recorded with a Varian Mercury 400 spectrometer.

Synthesis of the monomers. End-on monomers CBZ-OX (Scheme S1) were synthesized in three steps from 2-methoxy-9H-carbazole, which was prepared from 4-methoxy-2'nitrobiphenyl via a Cadogan reductive cyclization as reported previously. ${ }^{1-3}$ Specifically, methylation of the nitrogen atom of the carbazole heterocycle to generate 2-methoxy-9methyl-9H-carbazole (CBZ-OMe), cleavage of the methoxy group to produce $\mathbf{C B Z - O H}$, and alkylation under the experimental conditions of either the Williamson's (CBZ-O3 and CBZ-O6) or the Mitsunobu's (CBZ-O11) reaction afford the target carbazole monomers CBZ-OX in overall yields of 32-42\%. Alkylation of 2-methoxy-9H-carbazole with 6-bromo-1-hexene furnished the side-on monomer, 9-(5-hexenyl)-2-methoxy-9Hcarbazole (CBZ-OMe-N6, Scheme S1), in a yield of 59\%. The structural identities of the final compounds were confirmed by electrospray ionization mass spectrometry (ESIMS) and ${ }^{1} \mathrm{H}$ nuclear magnetic resonance (NMR) spectroscopy. Both the nematic mesogen and the isotropic cross-linker (M4OMe and CL respectively, Scheme S1) were prepared following literature procedures. ${ }^{4,5}$ 
Scheme S1. Synthesis of the end-on carbazole fluorogenic monomers CBZ-O3, CBZ-O6 and CBZ-O11, and their side-on counterpart, CBZ-OMe-N6. Reaction conditions: (a) 1) NaH, DMF, RT; 2) MeI, RT; 3) $\mathrm{BBr}_{3}, \mathrm{CH}_{2} \mathrm{Cl}_{2},-78^{\circ} \mathrm{C}$; 4) $-78^{\circ} \mathrm{C} \rightarrow \mathrm{RT}$; (b) For CBZ-O3 and CBZ-O6: 1) $\mathrm{NaH}$ or $\mathrm{K}_{2} \mathrm{CO}_{3}$, DMF, RT; 2) alkenyl bromide, RT; for CBZ-O11: 10-undecen-1-ol, $\mathrm{PPh}_{3}$, DIPAD, THF, RT; (c) 1) NaH, DMF, RT; 2) 6-bromo-1-hexene, RT.

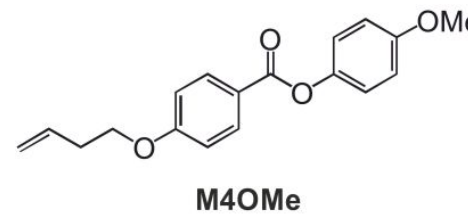

Nematic Monomer

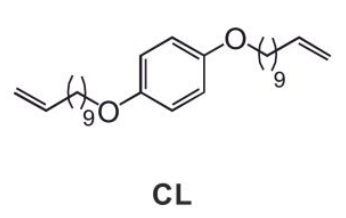

Isotropic Cross-linker

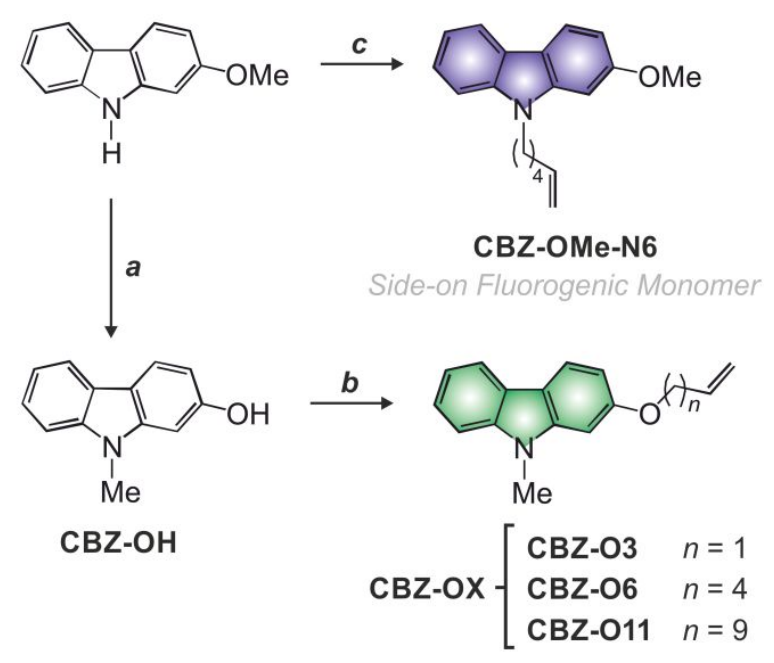

End-on Fluorogenic Monomers

2-methoxy-9-methyl-9H-carbazole (CBZ-OMe). $\mathrm{NaH}$ (2.973 g, $74.32 \mathrm{mmol}, 60 \%$ dispersion in mineral oil) was added portion wise to a solution of 2-methoxy- $9 \mathrm{H}$ carbazole $(2.436 \mathrm{~g}, 12.35 \mathrm{mmol})$ in anhydrous DMF $(15 \mathrm{~mL})$ under inert atmosphere. The resulting solution was stirred at room temperature for 1 hour. After, methyl iodide $(0.84$ $\mathrm{mL}, 13.50 \mathrm{mmol}$ ) was added and the reaction mixture was stirred at room temperature for 3 hours. Then, the mixture was poured into ice-water with the concomitant precipitation of a white solid. The precipitate was filtered off and recrystallized from methanol to afford CBZ-OMe (2.316 g, $10.96 \mathrm{mmol}, 89 \%$ ) as a white solid. ${ }^{1} \mathrm{H}$ NMR (400 MHz, $d_{6}$-acetone,

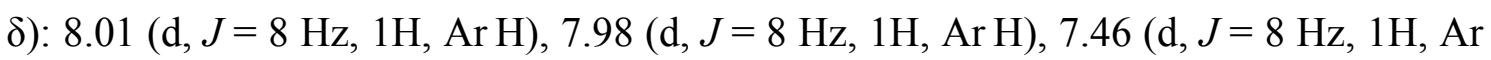
H), 7.36 (ddd, $J=8 \mathrm{~Hz}, 8 \mathrm{~Hz}, 1 \mathrm{~Hz}, 1 \mathrm{H}, \mathrm{Ar} \mathrm{H}), 7.16$ (ddd, $J=8 \mathrm{~Hz}, 8 \mathrm{~Hz}, 1 \mathrm{~Hz}, 1 \mathrm{H}, \mathrm{Ar}$ 
H), $7.08(\mathrm{~d}, J=2 \mathrm{~Hz}, 1 \mathrm{H}, \mathrm{Ar} \mathrm{H}), 6.82(\mathrm{dd}, J=8 \mathrm{~Hz}, 2 \mathrm{~Hz}, 1 \mathrm{H}, \mathrm{Ar} \mathrm{H}), 3.92\left(\mathrm{~s}, 3 \mathrm{H}, \mathrm{CH}_{3}\right)$, $3.87\left(\mathrm{~s}, 3 \mathrm{H}, \mathrm{CH}_{3}\right) \mathrm{ppm}$.

2-hydroxy-9-methyl-9H-carbazole (CBZ-OH). A $1 \mathrm{M}$ solution of $\mathrm{BBr}_{3}$ in $\mathrm{CH}_{2} \mathrm{Cl}_{2}(25.3$ $\mathrm{mL}$ ) was added dropwise over CBZ-OMe (2.000 g, $9.47 \mathrm{mmol})$ at $-78{ }^{\circ} \mathrm{C}$ under inert atmosphere. The resulting solution was warmed up to room temperature and stirred overnight. The reaction mixture was poured into ice-water and, then, a $1 \mathrm{M}$ sodium hydroxide solution was added until basic $\mathrm{pH}$. After, a 5\% (w/w) hydrochloric acid solution was slowly added until $\mathrm{pH}=4$. The product was extracted with ethyl acetate. The combined organic extract was dried over anhydrous $\mathrm{Na}_{2} \mathrm{SO}_{4}$, filtered and the solvent was distilled off under reduced pressure. The crude was purified by flash column chromatography using a mixture of hexane and $\mathrm{CH}_{2} \mathrm{Cl}_{2}(1: 2 \mathrm{v} / \mathrm{v})$ as the eluent to afford CBZ-OH (1.283 g, $6.50 \mathrm{mmol}, 69 \%)$ as a white solid. ${ }^{1} \mathrm{H}$ NMR (400 $\left.\mathrm{MHz}, \mathrm{CDCl}_{3}, \delta\right)$ : $7.98(\mathrm{~d}, J=8 \mathrm{~Hz}, 1 \mathrm{H}, \operatorname{ArH}), 7.91(\mathrm{~d}, J=8 \mathrm{~Hz}, 1 \mathrm{H}, \operatorname{Ar} \mathrm{H}), 7.41(\mathrm{~d}, J=8 \mathrm{~Hz}, 1 \mathrm{H}, \operatorname{Ar} \mathrm{H})$, $7.38(\mathrm{ddd}, J=8 \mathrm{~Hz}, 8 \mathrm{~Hz}, 1 \mathrm{~Hz}, 1 \mathrm{H}, \mathrm{Ar} \mathrm{H}), 7.18(\mathrm{ddd}, J=8 \mathrm{~Hz}, 8 \mathrm{~Hz}, 1 \mathrm{~Hz}, 1 \mathrm{H}, \mathrm{Ar} \mathrm{H})$, $6.80(\mathrm{~d}, J=2 \mathrm{~Hz}, 1 \mathrm{H}, \mathrm{Ar} \mathrm{H}), 6.70(\mathrm{dd}, J=8 \mathrm{~Hz}, 2 \mathrm{~Hz}, 1 \mathrm{H}, \mathrm{Ar} \mathrm{H}), 4.89(\mathrm{~s}, 1 \mathrm{H}, \mathrm{OH}), 3.78$ $\left(\mathrm{s}, 3 \mathrm{H}, \mathrm{CH}_{3}\right) \mathrm{ppm}$.

2-allyloxy-9-methyl-9H-carbazole (CBZ-O3). $\mathrm{NaH}$ (365 mg, 9.13 mmol, 60\% dispersion in mineral oil) was added portion wise to a solution of CBZ-OH (300 mg, 1.52 mmol) in anhydrous DMF (6 mL). The resulting solution was stirred at room temperature under inert atmosphere for 2 hours. After, allyl bromide $(0.64 \mathrm{~mL}, 7.40 \mathrm{mmol})$ was added and the reaction mixture was stirred at room temperature for 72 hours. The reaction mixture was diluted with water and the product was extracted with $\mathrm{CH}_{2} \mathrm{Cl}_{2}$. The combined organic extract was dried over anhydrous $\mathrm{Na}_{2} \mathrm{SO}_{4}$, filtered and the solvent was distilled off under reduced pressure. The crude was purified by flash column chromatography using a mixture of hexane and $\mathrm{CH}_{2} \mathrm{Cl}_{2}(3: 1 \mathrm{v} / \mathrm{v})$ as the eluent to afford CBZ-O3 (250 $\mathrm{mg}$, 
$1.05 \mathrm{mmol}, 69 \%)$ as a white solid. ESIMS: $m / z=238.1227[\mathrm{M}+\mathrm{H}]^{+}(\mathrm{m} / z$ calcd. for $\left.\mathrm{C}_{16} \mathrm{H}_{16} \mathrm{NO}=238.1232\right) ;{ }^{1} \mathrm{H} \mathrm{NMR}\left(400 \mathrm{MHz}, \mathrm{CDCl}_{3}, \delta\right): 7.99(\mathrm{~d}, J=8 \mathrm{~Hz}, 1 \mathrm{H}, \mathrm{Ar} \mathrm{H})$, $7.96(\mathrm{~d}, J=8 \mathrm{~Hz}, 1 \mathrm{H}, \mathrm{Ar} \mathrm{H}), 7.41$ (ddd, $J=8 \mathrm{~Hz}, 8 \mathrm{~Hz}, 1 \mathrm{~Hz}, 1 \mathrm{H}, \mathrm{Ar} \mathrm{H}), 7.35$ (d, $J=8$ Hz, 1H, Ar H), 7.21 (ddd, $J=8$ Hz, 8 Hz, $1 \mathrm{~Hz}, 1 \mathrm{H}, \mathrm{Ar} \mathrm{H}), 6.86-6.90$ (m, 2H, Ar H), 6.15 (ddt, $J=17 \mathrm{~Hz}, 10 \mathrm{~Hz}, 5 \mathrm{~Hz}, 1 \mathrm{H},=\mathrm{CH}), 5.49\left(\mathrm{dd}, J=17 \mathrm{~Hz}, 1 \mathrm{~Hz}, 1 \mathrm{H},=\mathrm{CH}_{2}\right), 5.33(\mathrm{dd}$, $\left.J=10 \mathrm{~Hz}, 1 \mathrm{~Hz}, 1 \mathrm{H},=\mathrm{CH}_{2}\right), 4.68\left(\mathrm{~d}, J=5 \mathrm{~Hz}, 2 \mathrm{H}, \mathrm{CH}_{2}\right), 3.80\left(\mathrm{~s}, 3 \mathrm{H}, \mathrm{CH}_{3}\right) \mathrm{ppm}$.

2-(5-hexenyloxy)-9-methyl-9H-carbazole (CBZ-O6). NaH (365 mg, 9.13 mmol, 60\% dispersion in mineral oil) was added portion wise to a solution of CBZ-OH (300 mg, 1.52 mmol) in anhydrous DMF (6 mL) under inert atmosphere. The resulting solution was stirred at room temperature for 2 hours. After, 6-bromo-1-hexene (1.0 mL, $7.48 \mathrm{mmol})$ was added and the reaction mixture was stirred at $80{ }^{\circ} \mathrm{C}$ for 96 hours. The reaction mixture was diluted with water and the product was extracted with $\mathrm{CH}_{2} \mathrm{Cl}_{2}$. The combined organic extract was dried over anhydrous $\mathrm{Na}_{2} \mathrm{SO}_{4}$, filtered and the solvent was distilled off under reduced pressure. The crude was purified by flash column chromatography using a mixture of hexane and $\mathrm{CH}_{2} \mathrm{Cl}_{2}(3: 1 \mathrm{v} / \mathrm{v})$ as the eluent to afford CBZ-O6 $(228 \mathrm{mg}, 0.82$ mmol, 53\%) as a white solid. ESIMS: $m / z=280.1700[\mathrm{M}+\mathrm{H}]^{+}\left(\mathrm{m} / z\right.$ calcd. for $\mathrm{C}_{19} \mathrm{H}_{22} \mathrm{NO}$ $=280.1701) ;{ }^{1} \mathrm{H} \mathrm{NMR}\left(400 \mathrm{MHz}, \mathrm{CDCl}_{3}, \delta\right): 8.00(\mathrm{~d}, J=8 \mathrm{~Hz}, 1 \mathrm{H}, \operatorname{Ar} \mathrm{H}), 7.95(\mathrm{~d}, J=8$ Hz, 1H, Ar H), 7.41 (ddd, $J=8 \mathrm{~Hz}, 8 \mathrm{~Hz}, 1 \mathrm{~Hz}, 1 \mathrm{H}, \operatorname{Ar} \mathrm{H}), 7.35$ (d, $J=8 \mathrm{~Hz}, 1 \mathrm{H}, \operatorname{Ar} \mathrm{H})$, 7.21 (ddd, $J=8 \mathrm{~Hz}, 8 \mathrm{~Hz}, 1 \mathrm{~Hz}, 1 \mathrm{H}, \operatorname{Ar} \mathrm{H}), 6.83-6.88$ (m, 2H, Ar H), 5.88 (ddt, $J=17$ $\mathrm{Hz}, 10 \mathrm{~Hz}, 7 \mathrm{~Hz}, 1 \mathrm{H},=\mathrm{CH}), 5.08\left(\mathrm{dd}, J=17 \mathrm{~Hz}, 1 \mathrm{~Hz}, 1 \mathrm{H},=\mathrm{CH}_{2}\right), 5.01(\mathrm{dd}, J=10 \mathrm{~Hz}$, $\left.1 \mathrm{~Hz}, 1 \mathrm{H},=\mathrm{CH}_{2}\right), 4.11\left(\mathrm{t}, J=6 \mathrm{~Hz}, 2 \mathrm{H}, \mathrm{CH}_{2}\right), 3.80\left(\mathrm{~s}, 3 \mathrm{H}, \mathrm{CH}_{3}\right), 2.15-2.22\left(\mathrm{~m}, 2 \mathrm{H}, \mathrm{CH}_{2}\right)$, 1.85-1.93 (m, 2H, $\left.\mathrm{CH}_{2}\right), 1.60-1.70\left(\mathrm{~m}, 2 \mathrm{H}, \mathrm{CH}_{2}\right) \mathrm{ppm}$.

9-methyl-2-(10-undecenyloxy)-9H-carbazole (CBZ-O11). A solution of CBZ-OH (300 mg, $1.52 \mathrm{mmol}), \mathrm{PPh}_{3}(439 \mathrm{mg}, 1.67 \mathrm{mmol})$ and DIPAD $(0.36 \mathrm{~mL}, 1.83 \mathrm{mmol})$ in anhydrous THF $(25 \mathrm{~mL})$ was stirred at room temperature under inert atmosphere for $1 \mathrm{~h}$. 
After, 10-undecen-1-ol $(0.34 \mathrm{~mL}, 1.70 \mathrm{mmol})$ was added and the reaction mixture was stirred at room temperature for 48 hours. Then, the solvent was distilled off under reduced pressure. The crude was purified by flash column chromatography using a mixture of hexane and ethyl acetate (20:1 v/v) as the eluent to afford CBZ-O11 (340 mg, $0.97 \mathrm{mmol}$, 64\%) as a white solid. ESIMS: $m / z=350.2484[\mathrm{M}+\mathrm{H}]^{+}\left(m / z\right.$ calcd. for $\mathrm{C}_{24} \mathrm{H}_{32} \mathrm{NO}=$ 350.2484); ${ }^{1} \mathrm{H}$ NMR (400 MHz, $\left.\mathrm{CDCl}_{3}, \delta\right): 8.00(\mathrm{~d}, J=8 \mathrm{~Hz}, 1 \mathrm{H}, \mathrm{Ar} \mathrm{H}), 7.95(\mathrm{dd}, J=8$ $\mathrm{Hz}, 1 \mathrm{~Hz}, 1 \mathrm{H}, \mathrm{Ar} \mathrm{H}), 7.41(\mathrm{ddd}, J=8 \mathrm{~Hz}, 8 \mathrm{~Hz}, 1 \mathrm{~Hz}, 1 \mathrm{H}, \operatorname{Ar} \mathrm{H}), 7.35$ (d, $J=8 \mathrm{~Hz}, 1 \mathrm{H}$, Ar H), 7.21 (ddd, $J=8 \mathrm{~Hz}, 8 \mathrm{~Hz}, 1 \mathrm{~Hz}, 1 \mathrm{H}, \mathrm{Ar} \mathrm{H}), 6.84-6.88$ (m, 2H, Ar H), 5.84 (ddt, $J$ $=17 \mathrm{~Hz}, 10 \mathrm{~Hz}, 7 \mathrm{~Hz}, 1 \mathrm{H},=\mathrm{CH}), 5.08\left(\mathrm{dd}, J=17 \mathrm{~Hz}, 1 \mathrm{~Hz}, 1 \mathrm{H},=\mathrm{CH}_{2}\right), 5.01(\mathrm{dd}, J=10$ $\left.\mathrm{Hz}, 1 \mathrm{~Hz}, 1 \mathrm{H},=\mathrm{CH}_{2}\right), 4.10\left(\mathrm{t}, J=7 \mathrm{~Hz}, 2 \mathrm{H}, \mathrm{CH}_{2}\right), 3.80\left(\mathrm{~s}, 3 \mathrm{H}, \mathrm{CH}_{3}\right), 2.03-2.10(\mathrm{~m}, 2 \mathrm{H}$, $\left.\mathrm{CH}_{2}\right), 1.82-1.91\left(\mathrm{~m}, 2 \mathrm{H}, \mathrm{CH}_{2}\right), 1.48-1.57\left(\mathrm{~m}, 2 \mathrm{H}, \mathrm{CH}_{2}\right), 1.30-1.45\left(\mathrm{~m}, 10 \mathrm{H}, 5 \times \mathrm{CH}_{2}\right) \mathrm{ppm}$. 9-(5-hexenyl)-2-methoxy-9H-carbazole (CBZ-OMe-N6). NaH (304 mg, $7.61 \mathrm{mmol}$, $60 \%$ dispersion in mineral oil) was added portion wise to a solution of 2-methoxy- $9 \mathrm{H}$ carbazole $(250 \mathrm{mg}, 1.26 \mathrm{mmol})$ in anhydrous DMF $(7 \mathrm{~mL})$ under inert atmosphere. The resulting solution was stirred at room temperature for 1 hour. After, 6-bromo-1-hexene $(0.20 \mathrm{~mL}, 1.50 \mathrm{mmol})$ was added and the reaction mixture was stirred at room temperature overnight. The mixture was diluted with water and the product was extracted with $\mathrm{CH}_{2} \mathrm{Cl}_{2}$. The combined organic extract was dried over anhydrous $\mathrm{Na}_{2} \mathrm{SO}_{4}$, filtered and the solvent was distilled off under reduced pressure. The crude was purified by flash column chromatography using a mixture of hexane and $\mathrm{CH}_{2} \mathrm{Cl}_{2}(3: 1 \mathrm{v} / \mathrm{v})$ as the eluent to afford CBZ-OMe-N6 (210 mg, $0.75 \mathrm{mmol}, 59 \%$ ) as a white solid. ESIMS: $m / z=280.1697$ [M $+\mathrm{H}]^{+}\left(m / z\right.$ calcd. for $\left.\mathrm{C}_{19} \mathrm{H}_{22} \mathrm{NO}=280.1701\right) ;{ }^{1} \mathrm{H} \mathrm{NMR}\left(400 \mathrm{MHz}, \mathrm{CDCl}_{3}, \delta\right): 8.00(\mathrm{~d}, J$ $=8 \mathrm{~Hz}, 1 \mathrm{H}, \operatorname{Ar} \mathrm{H}), 7.97(\mathrm{dd}, J=8 \mathrm{~Hz}, 1 \mathrm{~Hz}, 1 \mathrm{H}, \operatorname{Ar} \mathrm{H}), 7.39$ (ddd, $J=8 \mathrm{~Hz}, 8 \mathrm{~Hz}, 1 \mathrm{~Hz}$, 1H, Ar H), 7.36 (d, $J=8 \mathrm{~Hz}, 1 \mathrm{H}, \mathrm{Ar} H), 7.21$ (ddd, $J=8 \mathrm{~Hz}, 8 \mathrm{~Hz}, 1 \mathrm{~Hz}, 1 \mathrm{H}, \mathrm{Ar} \mathrm{H}), 6.84-$ $6.88(\mathrm{~m}, 2 \mathrm{H}, \mathrm{Ar} \mathrm{H}), 5.77(\mathrm{ddt}, J=17 \mathrm{~Hz}, 10 \mathrm{~Hz}, 7 \mathrm{~Hz}, 1 \mathrm{H},=\mathrm{CH}), 5.00(\mathrm{dd}, J=17 \mathrm{~Hz}, 1$ 
$\left.\mathrm{Hz}, 1 \mathrm{H},=\mathrm{CH}_{2}\right), 4.96\left(\mathrm{dd}, J=10 \mathrm{~Hz}, 1 \mathrm{~Hz}, 1 \mathrm{H},=\mathrm{CH}_{2}\right), 4.26\left(\mathrm{t}, J=7 \mathrm{~Hz}, 2 \mathrm{H}, \mathrm{CH}_{2}\right), 3.95$ (s, 3H, $\left.\mathrm{CH}_{3}\right), 2.06-2.14\left(\mathrm{~m}, 2 \mathrm{H}, \mathrm{CH}_{2}\right), 1.84-1.93\left(\mathrm{~m}, 2 \mathrm{H}, \mathrm{CH}_{2}\right), 1.46-1.55\left(\mathrm{~m}, 2 \mathrm{H}, \mathrm{CH}_{2}\right)$ ppm.

Preparation of the LSCEs. A solution of the distinct monomers, i.e. M4OMe (80\% mol), CL $(10 \%$ mol) and the corresponding carbazole fluorophore (CBZ-OX or CBZ-OMeN6, 10\% mol), and polyhydrogenomethylsiloxane ( 85 $\mathrm{Si}-\mathrm{H}$ groups per chain) in thiophene-free toluene $(2 \mathrm{~mL})$ was placed in a spinning Teflon mould. A solution of cyclooctadieneplatinum (II) chloride in $\mathrm{CH}_{2} \mathrm{Cl}_{2}(1 \% \mathrm{w} / \mathrm{w}, 30 \mu \mathrm{L})$ was added and the reaction mixture was heated up to $75^{\circ} \mathrm{C}$ for 2 hours at $5000 \mathrm{rpm}$. Then, the mould was cooled down to room temperature and the elastomer (not totally cross-linked) was carefully removed from the wall. During the deswelling process, a uniaxial force was applied to the hung elastomer, parallel to its longest axis, in order to achieve a macroscopic orientation of the nematic directors. After, the cross-linking reaction was completed by leaving the elastomer under load in an oven at $75^{\circ} \mathrm{C}$ for 2 days. The nonreacted monomers were removed from the network by a swelling-deswelling process using toluene and hexane, respectively.

Characterization of the LSCEs. DSC thermograms were recorded with a Mettler-Toledo DSC 821 calorimeter at a scan rate of $4{ }^{\circ} \mathrm{C} \cdot \mathrm{min}^{-1}$ under a nitrogen flow. X-ray scattering experiments were performed in a PANalytical X'Pert PRO MPD $\theta / \theta$ powder diffractometer $($ radius $=240 \mathrm{~mm})$ with a PIXcel detector $\left(\right.$ active length $\left.=3.347^{\circ}\right)$ in a convergent beam configuration and a transmission geometry. All LSCEs were sandwiched between low absorbing polyester films (thickness $=3.6 \mu \mathrm{m}$ ). X-Ray scattering patterns were registered at room temperature with the monochromatic $\mathrm{Cu} \mathrm{K} \alpha$ radiation $(\lambda=1.5418 \AA)$ at an operating power of $45 \mathrm{kV}(40 \mathrm{~mA})$. Slits were adjusted in such a way that the height of the resulting incident beam was equal to $400 \mu \mathrm{m}$. A mask to 
define a beam length, in the axial direction, of about $4 \mathrm{~mm}$ was also used. $2 \theta / \theta$ scans were registered from $2 \theta=1^{\circ}$ to $2 \theta=60^{\circ}$ with a step size of $2 \theta=0.026^{\circ}$ and a measuring time of $300 \mathrm{~s}$ per step. On the other hand, all azimuthal scans were collected at a step size of $\varphi=1^{\circ}$ and a measuring time of $2.55 \mathrm{~s}$ per step. From the azimuthal distribution of intensities at a scattering vector corresponding to the maximum of the reflex located at $2 \theta$ $=19.7-20.0^{\circ}$, which follows a Gaussian function, the angular distribution of the mesogens with respect to the director can be calculated. The order parameter, $S$, has been determined using the method reported by Lovell and Mitchell. ${ }^{6,7}$

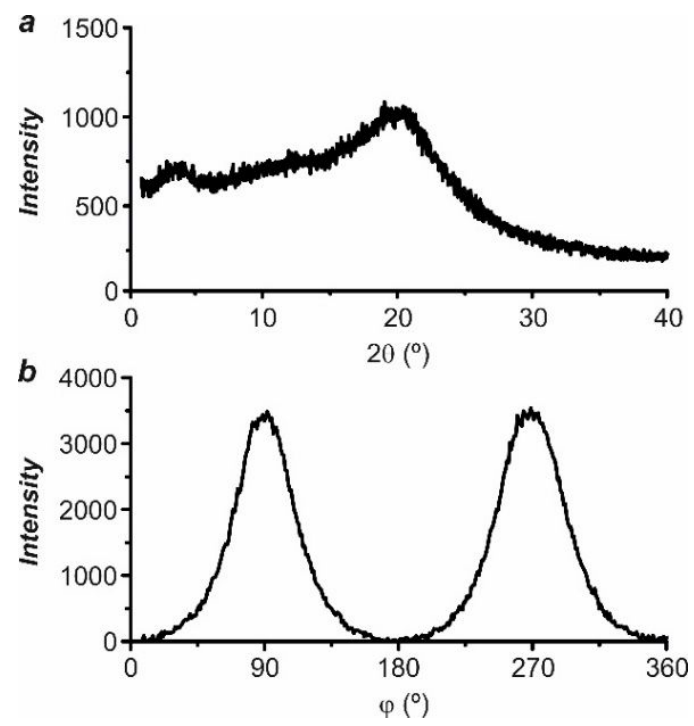

Figure S1. Characterization of the liquid single crystal elastomers: (a) X-ray diffraction pattern and $(\boldsymbol{b})$ azimuthal intensity distribution of the wide angle reflex at $2 \theta=19.7^{\circ}($ spacing $=4.5 \AA$ ) for the liquid single crystal elastomer ECBZ-O3.

Absorption and emission spectroscopies. Absorption spectra were recorded with a Varian Cary 500 E spectrometer, using quartz cells with a path length of $1.0 \mathrm{~cm}$. Excitation and emission spectra were recorded with a PTI 810 Series spectrometer (Birmingham, USA), equipped with a PTI 814 photomultiplier detection system and a USHIO Xenon Short Arc Lamp (Japan) installed in a PTI A-1010B arc lamp housing, 
under aerated conditions. Polarized excitation and emission spectra were recorded in the abovementioned spectrometer intercalating a Glan-Thompson polarizer either in the excitation or the emission beam.

Preparation of the fluorophore-doped polypropylene films for the determination of the transition dipole moment orientation. Polypropylene $(\mathrm{PP})$ films $(8 \mathrm{~cm}$ long $\times 2 \mathrm{~cm}$ wide $)$ were washed with chloroform for 1 hour to remove any possible additives or impurities. The clean and dry PP films were introduced in a $0.01 \mathrm{M}$ chloroform solution of the corresponding carbazole fluorophore (CBZ-NMe or CBZ-OMe) for 24 hours. After, the films were washed with absolute ethanol and dried. Finally, the PP films were stretched, along their longest axis, with a Hounsfield tensometer up to a final length about 3 times its initial value.

Mechanofluorescent experiments. Mechanofluorescent experiments were performed with a PTI 810 Series spectrometer (see above) controlled by a PC equipped with the PTI Felix32 software. All mechanofluorescent experiments were carried out by gluing the elastomeric samples by both ends into a self-constructed setup. LSCE samples were attached to the sample holder the previous day of the experiment to ensure thermodynamic equilibrium in the system. The sample was placed inside the spectrometer in a front-face geometry. In all instances, carbazole fluorophores were excited at a $\lambda_{\mathrm{Ex}}$ of $315 \mathrm{~nm}$, with light polarized perpendicular to the longest axis of the elastomeric material by means of a Glan Thompson polarizer placed between the light source and the sample; the resulting luminescence was collected at $\lambda_{\mathrm{Em}}=360 \mathrm{~nm}$. All experiments were carried out under ambient conditions. Once the first emission spectrum was collected a uniaxial deformation along the director direction of the elastomeric material was applied stepwise and the variation in the emission intensity at $\lambda_{\mathrm{Em}}=360 \mathrm{~nm}$ was monitored. After deformation, the elastomeric sample was left to equilibrate for 15 minutes prior to each 
spectrum collection. The collected spectra were later transferred to a commercially available software for further data treatment.

\section{References}

[1] Holzapfel, C. W.; Dwyer C. Stille and Suzuki Cross Coupling Reactions of $o$ Nitrophenyl Triflates: A Versatile Route to a Variety of Heterocycles. Heterocycles 1998, 48, 1513-1518.

[2] Cadogan, J. I. G.; Cameron-Wood, M.; Mackie, R. K.; Searle, R. J. G. The Reactivity of Organophosphorus Compounds. Part XIX. Reduction of NitroCompounds by Triethyl Phosphite: a Convenient New Route to Carbazoles, Indoles, Indazoles, Triazoles, and Related Compounds. J. Chem. Soc. 1965, 4831-4837.

[3] Díaz, J. L.; Dobarro, A.; Villacampa, B.; Velasco, D. Structure and Optical Properties of 2,3,7,9-Polysubstituted Carbazole Derivatives. Experimental and Theoretical Studies. Chem. Mater. 2001, 13, 2528-2536.

[4] Gray, G. W.; Jones, B. The Mesomorphic Transition Points of the para-normalAlkoxybenzoic Acids - a Correction. J. Chem. Soc. 1953, 4179-4180.

[5] Squires, A. M.; Tajbakhsh, A. R.; Terentjev, E. M. Dynamic Shear Modulus of Isotropic Elastomers. Macromolecules 2004, 37, 1652-1659.

[6] Lovell, R.; Mitchell, G. R. Molecular Orientation Distribution Derived from an Arbitrary Reflection. Acta Cryst. 1981, A37, 135-137.

[7] Mitchell, G. R.; Windle, A. Orientation in Liquid Crystal Polymers, in Developments in Crystal Polymers - 2, Basset, D. C. (Ed.), Science, London, New York, 1988, pp 115-175. 